\title{
Газохроматографическое определение свободных сахаров в изолятах соевого белка
}

\author{
Миляев А.С. ${ }^{1}$, Крысанова Т.А. ${ }^{2}$ \\ ${ }^{I}$ Открытое акциионерное общество «Инновационный изентр «Бирюч - Новые технологии», Алексеевка \\ ${ }^{2}$ ФББОУ ВО «Воронежский государственный университет», Воронеж \\ Поступила в редакцию 15.05.2018 г.
}

DOI: https://doi.org/10.17308/sorpchrom.2018.18/543

Разработана методика газохроматографического определения свободных сахаров (глюкоза, сахароза, раффиноза, стахиоза) с применением внутреннего стандарта - трикаприна. Для установления коэффициентов чувствительности использовали стандарты сахаров глюкозы, сахарозы, раффинозы и стахиозы компании SigmaAldrich в совокупности с расчетным методом. Результаты исследования представляют интерес в области аналитического контроля производства продуктов переработки сои, в частности, изолятов соевого белка.

Ключевые слова: газовая хроматография, соя, свободные сахара, изолят соевого белка.

\section{Gas-chromatographic determination of free sugar in soy protein isolate}

\author{
Milyaev A.S. ${ }^{1}$, KrysanovaT.A. $^{2}$ \\ ${ }^{I}$ Open join stock company «EFKO», Alekseevka \\ ${ }^{2}$ Voronezh State University, Voronezh
}

The results of determination of free sugars (glucose, sucrose, raffinose, stachyose) in soy protein isolates by gas chromatography are presented in the article. The aim of the study was to separately determine glucose, sucrose, raffinose and stachyose in isolates of soy protein (\%) by gas chromatography.

Determination of free sugars in soy protein isolates was carried out by gas chromatographic analysis. Glucose, sucrose, raffinose and stachyose, extracted with methanol from samples of soy protein isolates, were concentrated in a fume hood in a stream of nitrogen. Further, the dry residue was silylated with Nmethyl-N- (trimethylsilyl) trifluoroacetamide (MSTFA) and chlorotrimethylsilane (TMCS) in pyridine at $60^{\circ} \mathrm{C}$ for 1 hour. The resulting solution was diluted 10 -fold and part of the solution was placed in a $2-\mathrm{cm}^{3}$ chromatographic vial. For the analysis, $1 \mu$ of the sample was used, which was injected into the evaporator using an autosampler. Separation of free sugars was carried out on the capillary column DB-5HT (phase (5\% -phenyl)-methyl polysiloxane). Mobile phase: helium. Detection was carried out using a flame ionization detector of a gas chromatograph. The determination was made using the internal standard - tricaprin. Sugar glucose, sucrose, raffinose and stachyose sugars from SigmaAldrich were used in conjunction with the calculation method to establish the sensitivity coefficients.

During the development of the methodology a number of commercial samples of soy protein isolates were analyzed. The model Sansun 90 DN, Isolate DB 909 and Oil, according to the passport, the carbohydrate content is not more than $0.50 \%$, which is confirmed experimentally. According to the passports, samples SunSoy 690, Pro - Vo 500 and Pro-Vo DR1 carbohydrate content should not exceed 0.10\%, however, it was experimentally established that the total content of free sugars in these samples is overstated and is 0.34 ; 0.25 and $0.30 \%$, respectively. Also, overestimation of passport data is observed for the model BS-90 Dalian. 
The results of the study are interesting and practically applicable in the field of analytical control of soybean processing products production, in particular, soy protein isolates. As well as this technique is necessary for the incoming quality control of soy protein isolates in the production of baby food.

Keywords: gas chromatography, soy, free sugars, soy protein isolate.

\section{Введение}

Характерной особенностью сои является ее богатство белком и невысокое содержание углеводов. Углеводы в сое представлены растворимыми сахарами - моносахаридами (глюкозой, фруктозой) дисахаридами (сахарозой), трисахаридами (раффинозой), тетрасахаридами (стахиозой), а также гидролизуемыми полисахаридами (крахмалом) и нерастворимыми структурными полисахаридами (гемицеллюлозой, пектиновыми веществами, слизями и другими соединениями, образующими клеточные стенки). Во фракции растворимых углеводов моносахариды составляют лишь $1 \%$, а $99 \%$ представлены сахарозой, рафинозой и стахиозой. В расчете на сухое вещество семени в сое содержится 1.0-1.6 \% трисахаридарафинозы, которая состоит из молекул глюкозы, фруктозы и галактозы, а также 3.0-6.0 \% тетрасахарида стахиозы, образованной молекулами глюкозы, фруктозы и двумя молекулами галактозы [1].

Соевые бобы и продукты их переработки, такие как изоляты соевого белка, получили большую распространенность в современном мире. В частности, в продуктах питания (мясные и молочные продукты, кондитерские изделия, детское и спортивное питание), диетологии, косметологии и медицине. Зачастую качество продукта, его физико-химические и биологические свойства зависят от содержания углеводов в используемом сырье, что делает актуальным вопрос качественного и количественного свободных сахаров в продуктах переработки сои, в частности, изолятах соевого белка $[1,2]$.

Целью данной работы является разработка легко выполнимой, воспроизводимой и экспрессной методики количественного определения свободных сахаров в изолятах соевого белка.

\section{Эксперимент}

Определение содержания основного вещества в продуктах переработки сои проводили методом газовой хроматографии с применением внутреннего стандарта трикаприна. Для установления коэффициентов чувствительности использовали стандарты сахаров глюкозы, сахарозы, раффинозы и стахиозы компании SigmaAldrich (USA) с массовой долей основного вещества не менее 99,0 \%.

Подготовка растворов. Готовят стандартный раствор трикаприна концентрацией $32 \mathrm{мг} / \mathrm{cm}^{3}$ в пиридине. Для этого в мерной колбе объемом $10 \mathrm{~cm}^{3}$ взвешивают $(4.0000 \pm 0.0005)$ г трикаприна при перемешивании доводят до метки пиридином.

Для приготовления градуировочных растворов в отдельные химические стеклянные виалы, объемом 10-20 $\mathrm{cm}^{3}$ берут различные навески сахаров (от 20 до 100 мг). К навескам автоматическим дозатором добавляют $0.8 \mathrm{~cm}^{3}$ стандартного раствора трикаприна, $0.5 \mathrm{~cm}^{3}$ пиридина, $0.3 \mathrm{~cm}^{3} \quad \mathrm{~N}$-метил-N-(триметилсилил)трифторацетамид (MSTFA), и $0.1 \mathrm{~cm}^{3}$ триметилхлорсилана (TMCS). Виалу герметично закрывают резиновой пробкой, обжимают железной крышкой и помещают в сушильный шкаф при температуре $60^{\circ} \mathrm{C}$ на 60 мин (периодически виалы встряхивают). После сушильного шкафа, силилированные образцы охлаждают до комнатной температуры и приливают $2 \mathrm{~cm}^{3}$ гексана. Часть калибровочного раствора переносят в хроматографическую виалу объемом $2 \mathrm{~cm}^{3}$. 
Условия хроматографирования. Анализ проводили на газовом хроматографе Brucker 451 GC с пламенно-ионизационным детектором (ПИД). Для разделения компонентов применялась капиллярная колонка BR-5ht (30 мх0.25 ммх0.1 мкм) с неподвижной фазой - 100\% диметилполисилоксаном.

Выбраны следующие условия хроматографирования: объем ввода пробы 1 мкл, газ носитель - гелий, функция постоянной линейной скорости $40 \mathrm{~cm} / \mathrm{c}$, температура испарителя $-360^{\circ} \mathrm{C}$, деление потока $-40: 1$. Программирование термостата: начальная температура $150^{\circ} \mathrm{C}$, подъем до $360^{\circ} \mathrm{C}$ со скоростью $20^{\circ} \mathrm{C} / \mathrm{Mин,} \mathrm{конечная}$ температура выдерживается в течение 10 минут.

Установление коэффициента чувствительности. Градуировочную функцию рассчитывают по следующей формуле, полученной из экспериментальных данных при использовании метода линейной регрессии:

$$
\frac{M_{\text {sugar }}}{M_{\text {st }}}=k_{\text {sugar }} \cdot \frac{S_{\text {sugar }}}{S_{\text {st }}}
$$

где $M_{\text {sugar }}$ - масса сахара, мг; $M_{s t}$ - масса внутреннего стандарта (трикаприна),мг; $S_{\text {sugar }}$ - площадь пика сахара; $S_{s t}$ - площадь пика внутреннего стандарта; $k_{\text {sugar }}-$ коэффициент чувствительности.

Определение массовой доли свободных сахаров в анализируемом образце.

1) Проведение экстракции свободных сахаров. В химической стеклянной виале объемом $20 \mathrm{~cm}^{3}$ взвешивают $(500 \pm 10)$ мг образца результат взвешивания записывают с точностью до 0.0001 г. Далее в эту же виалу добавляют с помощью градуированной пипетки $10 \mathrm{~cm}^{3}$ внутреннего стандарта (п. 5.1) и автоматического дозатора $1 \mathrm{~cm}^{3}$ метанола, а затем её герметично закрывают. Виалу помещают для перемешивания на орбитальный шейкер в течение 1 часа. Затем центрифугируют в течение 10 мин со скоростью 1370 об/мин. После отбирают аликвоту объёмом $1 \mathrm{~cm}^{3}$ и помещают в виалу объемом $10 \mathrm{~cm}^{3}$. Виалу с аликвотой помещают в вытяжной шкаф и сушат при в токе азота.

2) Силилирование свободных сахаров. В охлаждённую до комнатной температуры виалу добавляют по $0.5 \mathrm{~cm}^{3}$ пиридина, $0.3 \mathrm{~cm}^{3}$ MSTFA и $0.05 \mathrm{~cm}^{3}$ TMCS. Виалу герметично закрывают резиновой пробкой, обжимают железной крышкой и помещают в сушильный шкаф при температуре $60^{\circ} \mathrm{C}$ на 60 мин (периодически виалы встряхивают). Затем виалу охлаждают до комнатной температуры и с помощью дозатора добавляют $2 \mathrm{~cm}^{3}$ гексана. Часть раствора переносят в хроматографическую виалу объемом $2 \mathrm{~cm}^{3}$.

\section{Обсуждение результатов}

На рис. 1 представлена хроматограмма калибровочного раствора, содержащего свободные сахара (глюкозу, сахарозу, раффинозу и стахиозу). Анализ калибровочных растворов при тех же условиях, что были использованы для анализа образца, позволяет идентифицировать пики сахаров путем сравнения времени удерживания.

Содержание свободных сахаров $\left(\omega_{\text {sugar }}, \%\right)$ в анализируемом образце рассчитывают по формуле:

$$
\omega_{\text {sugar }}=\omega_{\text {glu cose }}+\omega_{\text {sucrose }}+\omega_{\text {raffinose }}+\omega_{\text {stachyose }}
$$

где $\omega_{\text {glu cose }}$ - массовая доля глюкозы, $\%$; $\omega_{\text {sucrose }}-$ массовая доля сахарозы, \%; $\omega_{\text {raffinose }}$ - массовая доля раффинозы, \%; $\omega_{\text {stachyose }}$ - массовая доля стахиозы, \%. 
Содержание каждого сахара $\left(\omega_{i}, \%\right)$ в анализируемом образце рассчитывают отдельно по формуле [6]:

$$
\omega_{i}=\left[k_{i} \cdot\left(\frac{S_{i}}{S_{s t}}\right)\right] \cdot\left(\frac{M_{s t}}{M_{\text {obrz }}}\right) \cdot\left(\frac{\omega_{\text {water }}}{100}\right) \cdot 100 \%,
$$

где $\mathrm{k}_{\mathrm{i}}$ - коэффициент чувствительности к одному из сахаров; $\mathrm{M}_{\mathrm{obrz}}$ - масса высушенного и измельчённого образца, мг; $\omega_{\text {water }}$ - результат анализа (влажности) на влагомере, $\%$.

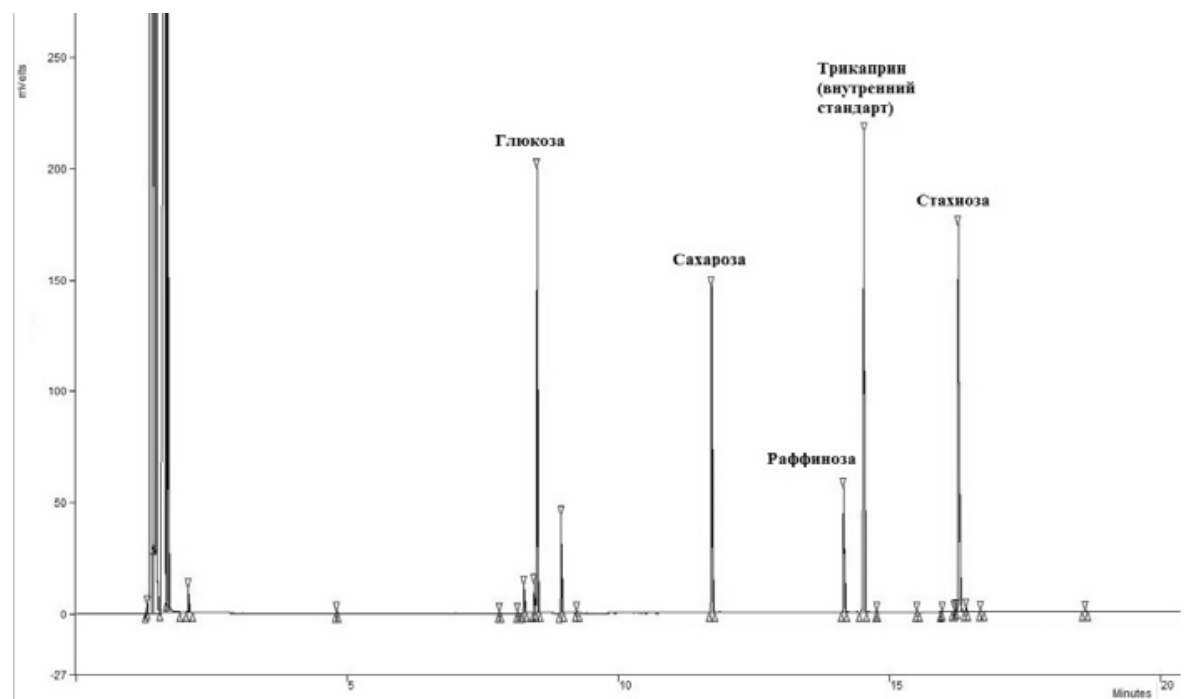

Рис. 1. Хроматограмма калибровочного раствора, содержащего глюкозу, сахарозу, раффинозу, стахиозу и внутренний стандарт (трикаприн), в координатах показания детектора (мВ) - время выхода компонентов (мин.).

На рис. 2 приведена типовая хроматограмма анализируемого образца изолята соевого белка китайских производителей «Шансунь 90», который является одним из самых популярных в мире. Исходя из вида хроматограммы, можно сделать вывод о том, что выбранные условия хроматографирования являются оптимальными, доказательством чему служат незначительная продолжительность анализа (около 20 минут), высокое разрешение хроматографических пиков и рост эффективности колонки.

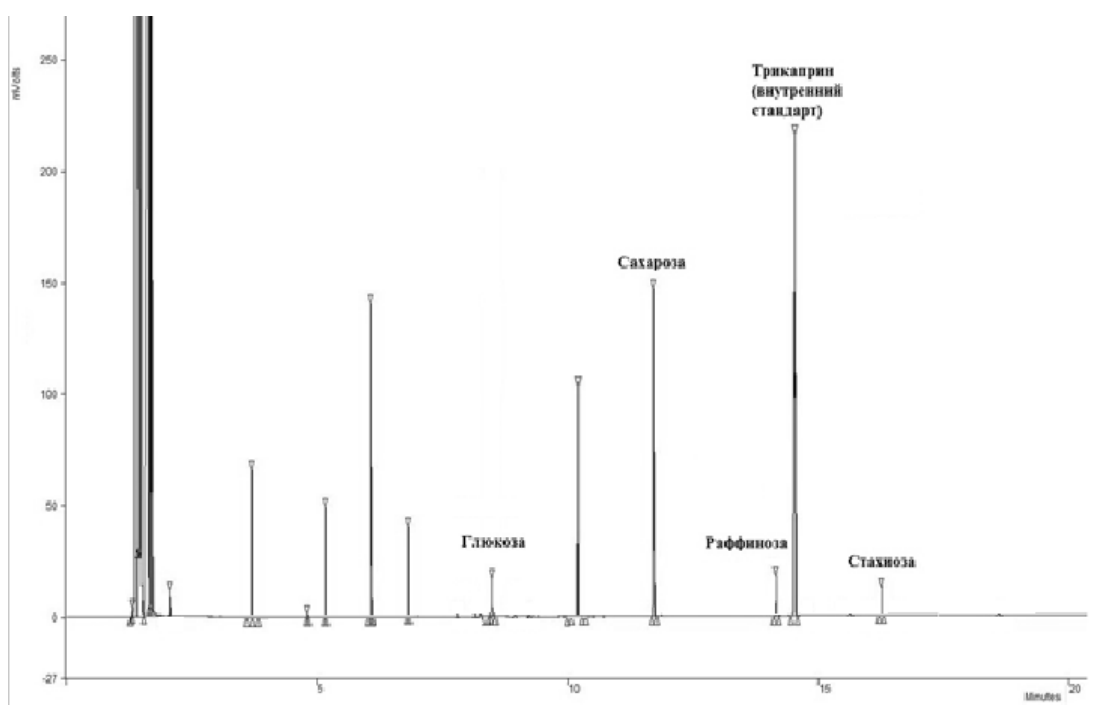

Рис. 2. Хроматограмма реального образца Шансунь 90 DN, содержащего глюкозу, сахарозу, раффинозу, стахиозу и внутренний стандарт (трикаприн). 
В ходе работы были проанализированы несколько коммерческих образцов изолятов соевого белка (таблица 1). Выявлено, что относительное стандартное отклонение между результатами трех независимых единичных определений, выполненных при использовании одного метода, на идентичном испытуемом материале, в одной лаборатории, одним аналитиком и на одном оборудовании, находится в пределах 3\%. Метод является достаточно точным, наибольшая относительная погрешность наблюдается при малом содержании сахаров (около 1.51\%).

Таблица 1. Результаты внутрилабораторных испытаний различных коммерческих образцов изолятов соевого белка

\begin{tabular}{|c|c|c|c|c|c|c|c|}
\hline \multirow{2}{*}{ Образец } & \multirow{2}{*}{$\begin{array}{c}\text { Наименование } \\
\text { показателей }\end{array}$} & \multicolumn{3}{|c|}{$\mathrm{x}_{\mathrm{i}, \%}, \%$} & \multirow{2}{*}{$x^{\prime}, \%$} & \multirow{2}{*}{$\mathrm{S}(\mathrm{x})^{*}$} & \multirow{2}{*}{$\mathrm{S}_{\mathrm{r}}(\mathrm{x}), \%{ }^{* *}$} \\
\hline & & 1 & 2 & 3 & & & \\
\hline \multirow{5}{*}{ Шансунь 90 DN } & глюкоза & 0.155 & 0.156 & 0.158 & 0.156 & 0.002 & 0.98 \\
\hline & caxapoza & 0.101 & 0.100 & 0.099 & 0.100 & 0.001 & 1.00 \\
\hline & раффиноза & 0.051 & 0.051 & 0.050 & 0.51 & 0.001 & 1.14 \\
\hline & стахиоза & 0.098 & 0.099 & 0.100 & 0.099 & 0.001 & 1.01 \\
\hline & сумма & 0.405 & 0.406 & 0.407 & 0.406 & 0.001 & 0.25 \\
\hline \multirow{5}{*}{ Изолят DB 909} & глюкоза & $<0.01$ & $<0.01$ & $<0.01$ & $<0.01$ & - & - \\
\hline & caxapoza & 0.395 & 0.396 & 0.393 & 0.395 & 0.002 & 0.39 \\
\hline & раффиноза & $<0.01$ & $<0.01$ & $<0.01$ & $<0.01$ & - & - \\
\hline & стахиоза & 0.081 & 0.082 & 0.081 & 0.081 & 0.001 & 0.71 \\
\hline & сумма & 0.476 & 0.478 & 0.474 & 0.476 & 0.002 & 0.42 \\
\hline \multirow{5}{*}{ SunSoy 690} & глюкоза & $<0.01$ & $<0.01$ & $<0.01$ & $<0.01$ & - & - \\
\hline & сахароза & 0.300 & 0.302 & 0.305 & 0.302 & 0.003 & 0.83 \\
\hline & раффиноза & $<0.01$ & $<0.01$ & $<0.01$ & $<0.01$ & - & - \\
\hline & стахиоза & 0.048 & 0.048 & 0.047 & 0.048 & 0.001 & 1.21 \\
\hline & сумма & 0.348 & 0.350 & 0.352 & 0.350 & 0.002 & 0.57 \\
\hline \multirow{5}{*}{ Pro - Vo 500} & глюкоза & $<0.01$ & $<0.01$ & $<0.01$ & $<0.01$ & - & - \\
\hline & сахароза & 0.250 & 0.256 & 0.253 & 0.253 & 0.003 & 1.19 \\
\hline & раффиноза & $<0.01$ & $<0.01$ & $<0.01$ & $<0.01$ & - & - \\
\hline & стахиоза & $<0.01$ & $<0.01$ & $<0.01$ & $<0.01$ & - & - \\
\hline & сумма & 0.250 & 0.256 & 0.253 & 0.253 & 0.003 & 1.19 \\
\hline \multirow{5}{*}{ Майсол } & глюкоза & $<0.01$ & $<0.01$ & $<0.01$ & $<0.01$ & - & - \\
\hline & сахароза & 0.199 & 0.203 & 0.205 & 0.202 & 0.003 & 1.51 \\
\hline & раффиноза & $<0.01$ & $<0.01$ & $<0.01$ & $<0.01$ & - & - \\
\hline & стахиоза & 0.049 & 0.048 & 0.048 & 0.048 & 0.001 & 1.19 \\
\hline & сумма & 0.248 & 0.251 & 0.253 & 0.251 & 0.003 & 1.00 \\
\hline \multirow{5}{*}{ Pro - Vo DR1 } & глюкоза & $<0.01$ & $<0.01$ & $<0.01$ & $<0.01$ & - & - \\
\hline & caxapoza & 0.304 & 0.305 & 0.310 & 0.306 & 0.003 & 1.05 \\
\hline & раффиноза & $<0.01$ & $<0.01$ & $<0.01$ & $<0.01$ & - & - \\
\hline & стахиоза & $<0.01$ & $<0.01$ & $<0.01$ & $<0.01$ & - & - \\
\hline & сумма & 0.304 & 0.305 & 0.310 & 0.306 & 0.003 & 1.05 \\
\hline \multirow{5}{*}{ BS - 90 Dalian } & глюкоза & 0.248 & 0.250 & 0.253 & 0.250 & 0.003 & 1.01 \\
\hline & сахароза & 0.480 & 0.470 & 0.469 & 0.473 & 0.006 & 1.29 \\
\hline & раффиноза & 0.074 & 0.075 & 0.075 & 0.075 & 0.001 & 0.77 \\
\hline & стахиоза & 0.230 & 0.321 & 0.225 & 0.229 & 0.003 & 1.14 \\
\hline & сумма & 1.032 & 1.026 & 1.022 & 1.027 & 0.005 & 0.49 \\
\hline
\end{tabular}

s (x) - стандартное отклонение; ${ }^{* *} \mathrm{~s}_{\mathrm{r}}(\mathrm{x})$ - относительное стандартное отклонение

В образцах Шансунь 90 DN, Изолят DB 909 и Майсол, согласно паспорту, содержание углеводов составляет не более $0.50 \%$, что подтверждается экспериментально. Согласно паспортам образцов SunSoy 690, Pro - Vo 500 и Pro - Vo DR1 co- 
держание углеводов должно быть не более $0.10 \%$, однако установлено, что суммарное содержание свободных сахаров в данных образцах завышено и составляет 0.34; 0.25 и $0.30 \%$ соответственно. Следует отметить, что для образца BS-90 Dalian мaccoвая доля свободных сахаров в 2 раза превышает заявленное по паспорту значение. Повышенные показатели в представленных образцах создают угрозу ошибочного несоблюдения рецептуры при приготовлении продуктов детского питания на основе изолятов соевого белка.

\section{Заключение}

Разработана методика газохроматографического определения свободных сахаров, позволяющая определять содержание сахаров в продуктах переработки сои. Выполненное исследование представляет интерес для специалистов в области аналитического контроля производства продуктов переработки сои (например, изолятов соевого белка).

\section{Список литературы}

1. Соя: Химический состав и использование / под редакцией В.М. Лукомца. Майкоп: ОАО «Полограф-ЮГ». 2012. 432 с.

2. Johnson L.A. // AOCS Press. 2008. 842 p.

3. Raynie D.E. // LCGC North America. 2018. Vol. 36. Issue 1. pp. 14-18.

4. Mir Ali Farajzadeh // TrAC Trends in Analytical Chemistry. 2014. Vol. 55. pp. 14-23.

\section{References}

1. Soybean: Chemical composition and use, Edited by Academician of the RAAS, Dr. of Agricultural Sciences. V.M. Lukomets, Maykop, OJSC «Polograf-Yug», 2012, 432 p.

2. Johnson L.A., AOCS Press, 2008, 842 p.

3. Raynie D.E., LCGC North America, 2018, Vol. 36, Issue 1, pp. 14-18.

4. Mir Ali Farajzadeh, TrAC Trends in Analytical Chemistry, 2014, Vol. 55, pp. 14-23.

Миляев Александр Сергеевич - магистр 2 г/о ВГУ, Воронеж, ведущий инженер-химик по внедрению инновационных методик ООО «ИЦ «Бирюч-НТ» ГК ЭФКО, Алексеевка

Крысанова Татьяна Анатольевна - к.х.н., доцент кафедры аналитической химии ВГУ, Воронеж.
5. Orata F. // INTECH Open Access Publisher. 2012. pp. 83-109.

6. ГОСТ Р 51483-99. Масла растительные и жиры животные. Определение методом газовой хроматографии массовой доли метиловых эфиров индивидуальных жирных кислот к их сумме. М. 2005. 11 с.

5. Orata F., INTECH Open Access Publisher, 2012, pp. 83-109.

6. State Standard 51483-99. Vegetable oils and fats animal. Determination by gas chromatography of constituent contents of methyl esters of total fatty acid content, M., StandartinformPubl., 2005, $11 \mathrm{p}$.

Milyaev Alexander S. - master Voronezh State University, Voronezh, chemical engineer «EFKO», Alekseevka, e-mail: a.milyaev@brc.efko.ru

Krysanova Tatiana A. - Ph.D., assistant professor Chair of Analytic Chemistry Voronezh State University, Voronezh, e-mail: takrys@yandex.ru 